\title{
Effect of integrated crop management on brinjal yield and economics through frontline demonstration at farmers field
}

\author{
Nagappa Desai*, Chandru Patil ${ }^{1}$ and B. Mamatha \\ Krishi Vigyan Kendra (U.A.S.), Konehalli, TUMKURU (KARNATAKA) INDIA \\ (Email : agridesai@gmail.com)
}

\begin{abstract}
The studies were conducted on effect of integrated crop management on brinjal yield and economics through frontline demonstration at farmers field of Tumkuru district, Karnataka state during the year 2009-10 to 2011-12. The data revealed that the total yield gap between potential yield and actual yield of brinjal was 53.67 per cent, in which 16.92 per cent of yield gap between demonstration plot and actual farmers plot yield and 36.75 per cent of technological gap. The maximum number of farmers were adopted recommended spacing $(88.33 \%)$ followed by seed treatment $(83.33 \%)$, timely irrigation $(81.67 \%)$ and weed management $(81.67 \%)$. The increased in adoption level of package of practices were found to more in raising and selection of quality seedling from nursery $(50.00 \%)$ fallowed by selection of high yielding hybrid variety $(46.67 \%)$ and application of vegetable special $(50.00$ $\%)$. Whereas, the package of practices viz., plant protection measures to control pest and diseases (21.67\%), application of recommended dose of fertilizer $(25.00 \%)$ and seed treatment $(26.67 \%)$ were found to less increase in adoption level after frontline demonstration. There was significantly increased in brinjal yield (36.51\%), net return and B:C ratio after conduct of frontline demonstrations as compared to farmers practice. The adoption of package of practices even though after demonstrations programme, which shows positive impact of integrated crop management on brinjal yield and economics through adoption of demonstrated technology.
\end{abstract}

Key Words : Adoption, Brinjal, Frontline demonstration, Integrated, Net return

View Point Article : Desai, Nagappa, Patil, Chandru and Mamatha, B. (2018). Effect of integrated crop management on brinjal yield and economics through frontline demonstration at farmers field. Internat. J. agric. Sci., 14 (1) : 154-159, DOI:10.15740/HAS/IJAS/14.1/ 154-159.

Article History : Received : 15.03.2017; Revised : 24.11.2017; Accepted : 07.12.2017

\footnotetext{
* Author for correspondence:

${ }^{1}$ Agricultural and Horticultural Research Station (U.A.H.S.), Sringeri, CHIKAMAGALUR (KARNATAKA) INDIA
} 